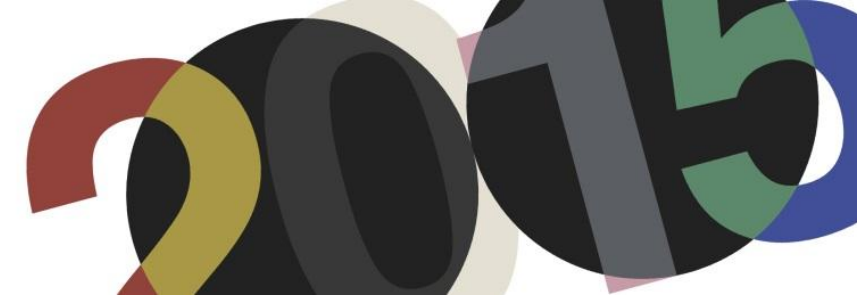

DOI: http://dx.doi.org/10.4995/LC2015.2015.947

\title{
The eye of the architect. Le Corbusier and the photograph: demonstrate, learn, remember
}

\author{
A. Teodosio \\ Department of Civil Engineering, University of Salerno (Italy)
}

\begin{abstract}
The relationship between Le Corbusier and the visual arts (drawing, photography and cinema) is deep and complex and, although the subject of numerous publications and research since the late 60s, still arouses much interest, as evidenced by the many events organized in the last years - "Le Corbusier. Vue sur la mer ", Maison La Roche, Paris, 2012; "Construire the image: Le Corbusier et la Photographie", Musée des Beaux-Arts, the Chaux-de-Fonds, 2013; or the recent "Le Corbusier and photography", IUAV, Venice, May 2015-. The paper, starting out from the researches already developed, proposes a further reflection on the relationship between the Swiss architect and the photography, paying particular interest to the shooting made in first person. The study analyzes the different approaches and the different subjects photographed in the course of his life and it is proposed to include the work of Le Corbusier in the broader cultural context of the twentieth century, a period in which the relationship between architecture and visual communication, thanks to the many possibilities offered by technological innovations, it becomes increasingly close and inevitable.
\end{abstract}

Resumen: La relación entre Le Corbusier y las artes visuales (dibujo, fotografía y cine) es profunda y articulada y, aunque es objeto de numerosas publicaciones y investigaciónes desde el finales de los años 60es, todavía despierta mucho interés, como lo demuestran los diversos eventos realizados en los últimos años - "Le Corbusier. Vue sur la mer", Maison La Roche, Parìs, 2012; "Construire l'image: Le Corbusier et la photographie”, Musée des Beaux-Arts, la Chaux-de-Fonds, 2013; o la más reciente "Le Corbusier e la fotografia", IUAV, Venezia, mayo 2015-. El artículo, a partir desde investigación ya desarrollado, propone una reflexión más sobre la relación entre el arquitecto suizo y la fotografía, prestando especial interés a las realizata en primera persona. El estudio analiza los diferentes enfoques y diferentes sujetos fotografiados en el curso de su vida y se propone de insertar la obra de Le Corbusier en el contexto cultural más amplio del siglo XX, un período en el que la relación entre la arquitectura y la comunicación visual, gracias a las muchas posibilidades que ofrecen las innovaciones tecnológicas, se vuelve cada vez más estrecha e inevitable.

Keywords: Le Corbusier; photography; representation of architecture.

Palabras clave: Le Corbusier; fotografia; representaciones de la arquitectura.

\section{Introduction}

Since the beginning of ' 900 journalists, critics and writers, but also many architects, make an extensive use of photography. The historiography traces back to the 30's already a deep and direct relationship between modern architecture and the new way to observe it. Many architects build personal archives that include images of ancient monuments but also of contemporary works and industrial buildings. As noted by the critic and theorist British Banham, the Modern Movement, for the first time in the history of art, is based almost exclusively on "photographic evidence" rather than on personal experience and direct survey ${ }^{1}$. The historic Pevsner, in his Pioneers of Modern Design (1936), makes extensive use of photographs to illustrate the texts and puts the accent

\footnotetext{
${ }^{1}$ Banham Reyner, A Concrete Atalantis. U.S. Industrial Building and European Modern Architecture, Cambridge-London: Mit-Pr 1986, p.18, work quoted by Fanelli Giovanni, Storia della fotografia di architettura, Roma-Bari: Laterza, 2009 , p.394
} 
on the power of the image by emphasizing the role of the photographer that, with his operational choices, is able to valorize or destroy the shooted handiwork of which, in a sense, becomes also author.

Also Le Corbusier bestows great importance to the expressiveness of his photographic work. Since the Twenties, he need the contribution of many photographers wherewith weaves deep associations: among them Charles Gérard, Georges Thiriet, Marius Gravot, which claims to have "elective affinities", Klaus Kinold, Lucien Hervé in which finds "an architect's soul". The architect works closely with professionals of lens and often influences their choices and their creative process. Some images, such as the famous atelier of Ozenfant ${ }^{2}$, become true icons of the Modern Movement and, as Giedion says, constitute a kind of self legitimization of modernism.

The photography for Le Corbusier is a vehicle to demonstrate his theses in Vers une architecture (1923); a propaganda for his work Oeuvre complète (1930-55), the first catalog made by an architect about his work; becomes a decorative element and the characterization of the interior space in the Swiss Pavilion in the University City of Paris, where 44 enlargements in black and white, rectangular or square, placed side by side seamlessly, give rise to a "fresque photographique".3.

The interest of Le Corbusier for the photographic representation is demonstrated by the large number of postcards purchased during his travels: images of landscapes and monuments, but also of modern architecture or projects that constitute material for subsequent studies or publications - as La construction des villes (1910) or, sometimes, the basis for drawings, sketches or notes. In this regard, very interesting is the postcard with the view of Notre-Dame of Paris, preserved by the Le Corbusier Foundation in Paris, on which he traces the proportional scheme of the facade and the cut margins for publication.

The evolution of the instruments and shooting techniques and the spread of portable appliances, lighter and easier to handle, allows architects to use firsthand photography to collect impressions and personal notes. Even Le Corbusier, starting from his youth travels, combines the traditional representations (written notes, sketches and drawings) with the photo shoots. He produces about 6000 shots that tell about the discovery of distant countries and cultures in the youthful period, exploratory trips preparatory for the implementation of projects such as the one in Brazil (1936) -, or intimate memories - as the summer holidays in Piquey, in the Bassin d'Arcachon -.

\section{Photographs of an architect in journey}

Le Corbusier, like Wright, is more prone to the drawing ${ }^{4}$. It seems to have no particular talent for photography, for which he declares to prove even embarrassment. In his writings he does not fail to underline its limits, saying that it cannot go beyond the crudest documentary aspect, and criticizes the fact that often it is delegated to the camera the task of looking at the world. Entrusting the emotions to the lens, you risk to forget to watch because, while the drawing presupposes long times of implementation and observation, the fleeting pressure on the button of a camera does not imply participation and does not gives time to fix the memory.

\footnotetext{
${ }^{2}$ Paris, atelier Ozenfant, photography by Charles Gérard, about 1924, published in Le Corbusier. Oeuvre complète, II, 1934.

${ }^{3}$ Definition used by Le Corbusier in his Oeuvre complète, II, 1934, p.77.

${ }^{4}$ Zannier Italo, "Nota a margine su Le Corbusier fotografo", in Giuliano Gresleri, Le Corbusier, Viaggio in Oriente. Charles, Edouard Jeanneret fotografo e scrittore, Venezia-Parigi: Marsilio-Fondation Le Corbusier, 3rd ed. 1995, pp. 479-482.
} 
However, the discovery and systematization of a rich photographic collection ${ }^{5}$, of which Le Corbusier is author, opens new glimmers on this personality so varied and complex, and broadens the interest from the simple analysis of the architectural work to the intellectual figure in its entirety. The large number of images retrieved, despite their unpretentious technique, demonstrate unequivocally that to the initial sense of rejection towards the photography, indeed, it joins together the attraction towards it. Also, they give impetus to a number of specific studies $^{6}$, thematic events and a heated debate on the relationship between the architect, the visual culture in general and the photograph in particular.

The photographic production of Le Corbusier can be divided into two major sections: that of his youth travels in Germany, Switzerland and Italy (1907) and in the East in 1911 - in which he made about 450 shots; and that of his maturity, of the '30s, in which the shooting makes sense and meaning profoundly different.

\subsection{From the city to the architecture...}

Despite his overt skepticism, Le Corbusier makes extensive use of photography not only in his publications, but also during his travels. Probably the first camera that he owns is a Kodak of small format that, as he wrote in some letters, only allows shooting of small size and poor quality, as those made in Italy, dark, blurred and that offering a distorted perception of the places ${ }^{7}$. In 1910 he buys a new camera for his trip to Germany. The drawings, still very close to the teachings of Sitte, the notes and the photographs reflect the search for new rules for the construction of the modern city and his personal insights ${ }^{8}$. In the many German cities he visits, he photographs urban hubs such as squares, widening and fountains, rather than individual monuments.

In May of 1911, before leaving for his trip to the Orient with his friend and student of art history August Klipstein, he buys a Cupid 80 camera, a professional device of which boasts the technical quality, and produces pictures in postcard format. From the early stages of this long "Grand Tour" his method of representation evolves: the drawings become drier and basic but rich in details and notes useful for his future work; the photograph, instead, is becoming increasingly important, and he will shoot approximately 450 pictures of which often is referenced in Carnets ${ }^{9}$. Even the represented subjects change: gradually the focus shifts from the built to details (frames, shelves, overhangs) that become a source of inspiration for his architecture. As noted by

\footnotetext{
${ }^{5}$ In 1982, the Fondation Le Corbusier entrusts to Gresleri the reordering of Le Corbusier iconographic material that converges in the text: Giuliano Gresleri, Le Corbusier, Viaggio in Oriente. Charles, Edouard Jeanneret fotografo e scrittore, Parigi: Fondation Le Corbusier, 1984.

${ }^{6}$ From the aforementioned study of Gresleri of 1984, which provides an initial assessment of photographs of Le Corbusier in his youth; to the essay by Thomas Schumacher "Deep space, Shallow space" published in Architectural Review (1987) with considerations on the photographic representation of architecture corbusiane in Oeuvre complète; to the studies by Beatriz Colomina "Le Corbusier und die Fotografie" and Stanislaus Von Moss "Im Vorzimmer des Machine Age" about photography as a means of propaganda of his ideas and his work published in the exhibition catalog L'Esprit Nouveau. Le Corbusier und die Industrie 1920-25, del 1987; to the work by Barbara Mazza, Le Corbusier e la fotografia. La vérité blanche (2002), that addresses comprehensively the complex relationships between the architect and photography; until the recent publication of Tim Burton, Le Corbusier, Secret Photographer (2013) which analyzes in detail the photographic production of the master.

${ }^{7}$ For a depth study based on detailed analysis of documents on equipment owned by Le Corbusier see: Cusano Federica, "Les voyages d'Italie", in AAVV, Le Corbusier. Aventures photographiques, Paris: Fondation Le Corbusier, 2014, pp. 3145.

${ }^{8}$ In this period Le Corbusier starts working at La construction des villes, work written between 1910 and 1915 and left unfinished.

${ }^{9}$ Mazza Barbara, Le Corbusier e la fotografia. La vérité blanche, Firenze: University Press, 2002, pp.23-24.
} 
Gresleri, you can trace a link between the attention paid to the double glazing of Malá Strana in Prague and the windows of the Maison Domino and villa Meyer ${ }^{10}$.

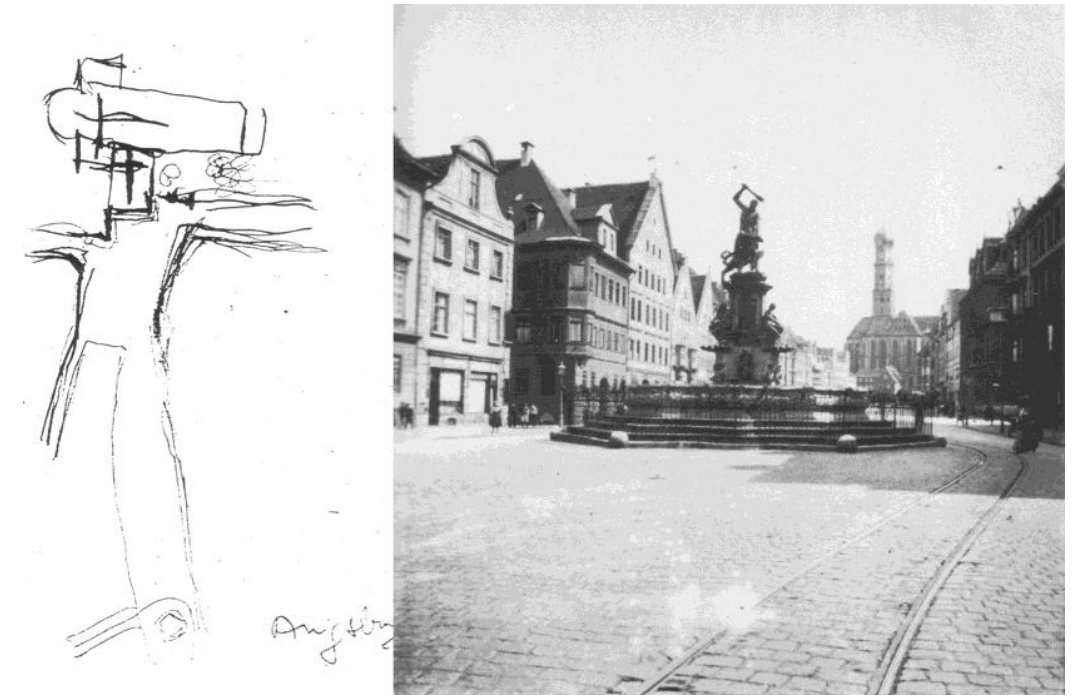

1. Le Corbusier, Augsburg (June 1910). Study of the site of Maximillianstrasse (from Le Corbusier, Carnet du Voyage d'Allemagne 2, p.143); view of Maximillianstrasse and of Sam Ulrich Cathedral (from G. Gresleri, Le Corbusier, Viaggio in Oriente., Charles, Edouard Jeanneret fotografo e scrittore, Venezia-Parigi: Marsilio-Fondation Le Corbusier, 3rd ed. 1995, pp. 156 e 157).

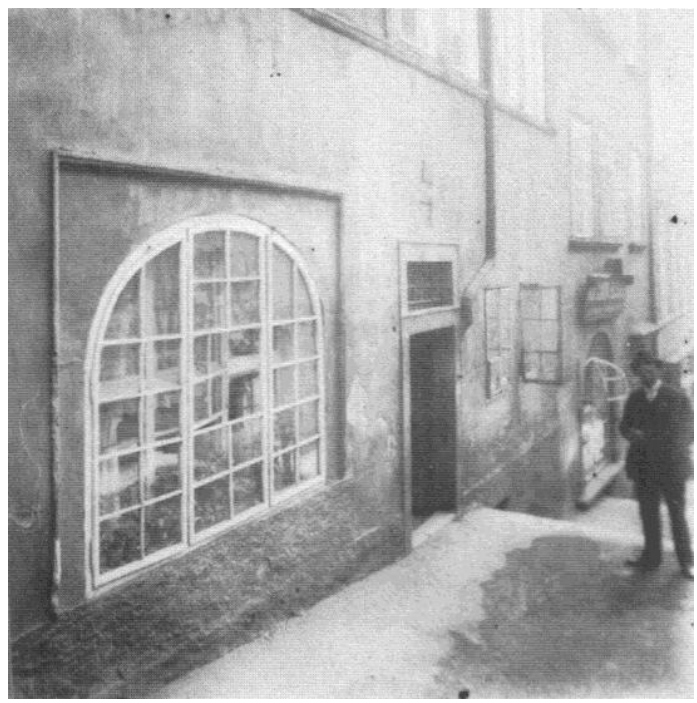

2. Le Corbusier, Prague (May 1911). Window on the stairs of Malá Strana (in Gresleri G., Op. Cit. p. 175).

If lacking images of Vienna, very documented is the route along the Danube and through the Balkans. Le Corbusier was very fascinated by the Hungarian, Bulgarian and Romanian countryside. He portrays the landscape with quick sketches, while reserves more precise technical drawings and spontaneous photographs to the architecture of the villages farmers. Numerous photos show simple traditional houses with large windows, porches and balconies; pergolas with vines and surrounding walls that hide courtyards filled with trees and plants. For the first time, ordinary people and scenes of peasant life are taken from his lens, while they are completely absent images of the Palace of Sinaia with its famous paintings by El Greco that, as is clear from his

\footnotetext{
${ }^{10}$ Gresleri G. (1995), Op. cit., p.61.
} 
diaries, he certainly sees. Unequivocal sign of the fact that his interests are changing and reflection turns increasingly to the simplicity of the places, forms and ways of living that have been lost elsewhere.

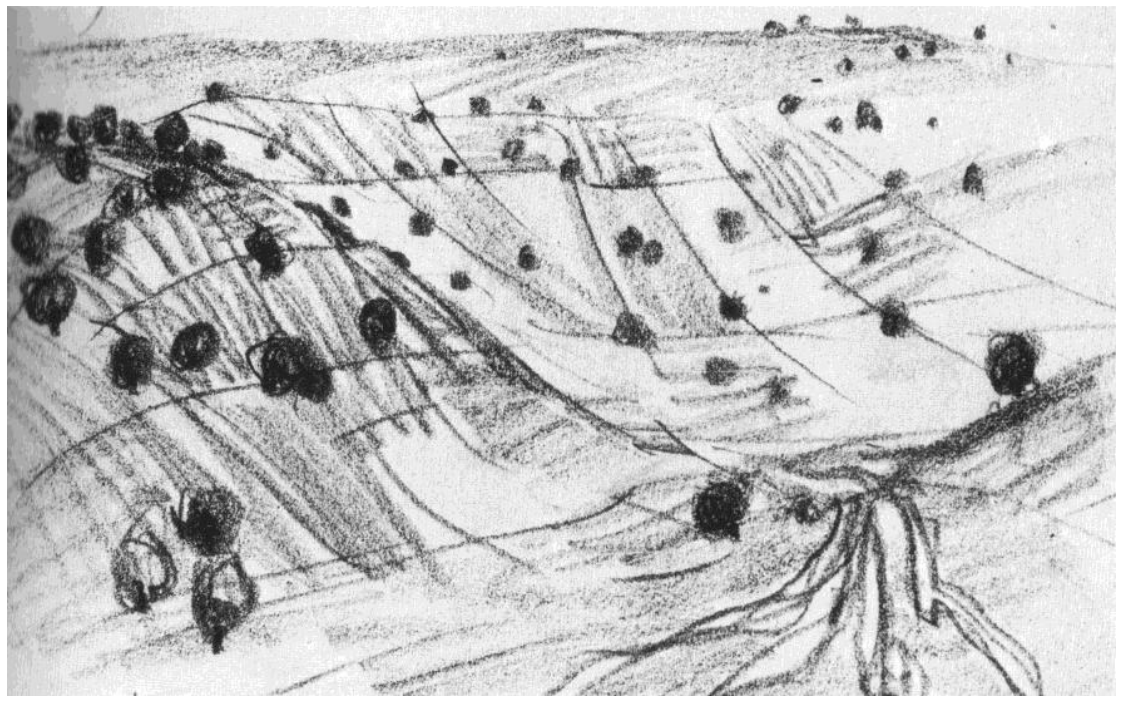

3. Le Corbusier, Bulgarian countryside (end of June 1911). Landscape with fields and trees. Pencil, pastel green and brown with traces of yellow, AFLC 6129 (from Gresleri.G, Op. Cit. p. 193).

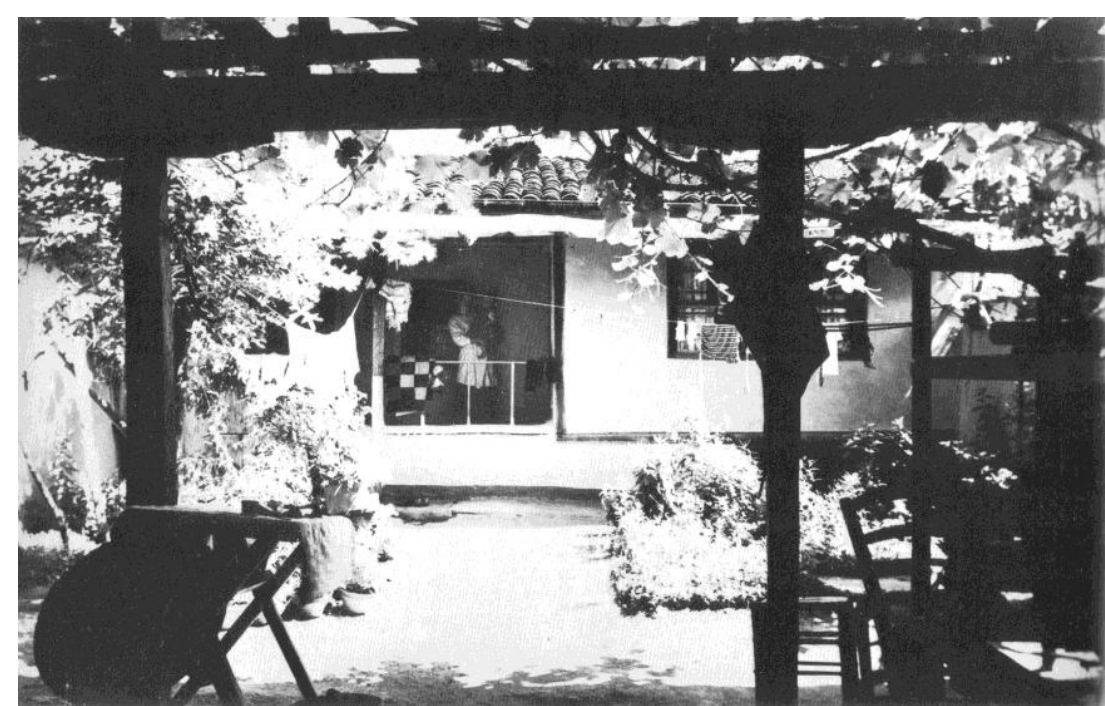

4. Le Corbusier, Kazanluk (July 1911). Courtyard with pergola and figure of a woman with child,. (from Gresleri G., Op. Cit. p. 206).

In Istanbul he wanders around the city without a predetermined path and prefers to entrust his feelings to the written description. Photographs the city from afar, from the west of Pera. From here, his camera placed on the window sill of his room, accidentally catches the blaze overnight in the city on 24 July 1911: "Tragic night! Great show, made of fire, people impassive and people upset, shouting and tears" ${ }^{11}$. Only Santa Sofia is an exception: the building is broken down and analyzed for parts, through the use of photography. As demonstrated by the shots taken, the architect shows a greater interest in the complex combination of volumes of facades rather than for the sensual interior decorations.

\footnotetext{
${ }^{11}$ Le Corbusier, Il disastro di Stambul, carnet July 2011, published in Gresleri G. (1995), Op.Cit., p.247.
} 


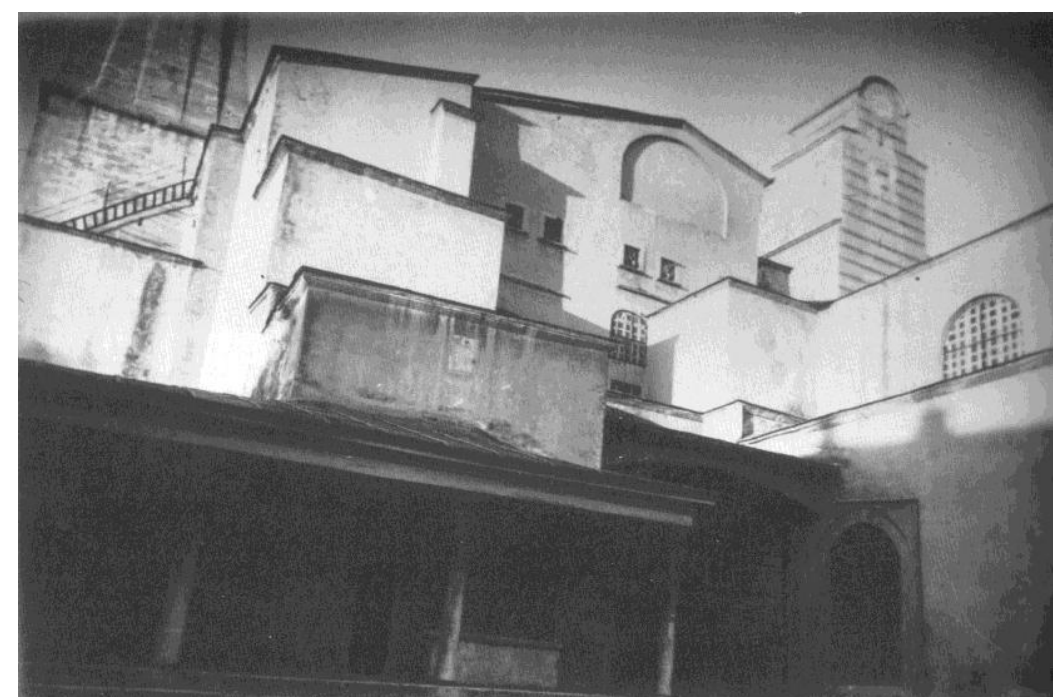

5. Le Corbusier, Instanbul (July, 1911). Santa Sofia, the spurs of the main entrance, south side. (from Gresleri G., Op. Cit. p. 272).

In Athens Le Corbusier photographs architectural details and even sculptural particulars preserved in the museum of the Acropolis, while leaving to the drawings the representation of the temples as part of a complex made up of natural elements and built.

In October 1911 in Naples he buys a Kodak Brownie with which he made about 120 shots of the city but also of Pompeii, Rome, Pisa. The images are lower quality but, as stated in one of his Carnet, he feels the need for a lighter instrument, which does not require a tripod, convenient to use and recharge. In Pompeii he takes numerous photos, often dark and out of focus: glimpses of streets and villas integrate technical drawings with dimensions and hypothetical reconstructions and reflections on living space. In Rome he photographs the ancient monuments, but with a glance very personal and functional to his interests. He tries to extract details of the architecture of Michelangelo in St. Peter's; he snaps a lot of stairs (from Piazza di Spagna to Villa Medici), a recurring theme in his iconography.

In Florence he photographs details of Santa Maria Novella and of the Giotto's bell tower, the side of the Cathedral and the Belfry, without worry of the scene, while he entrusts the representation of monuments in their context to the pencil sketches. In Pisa he photographs details and produces a poetic glimpse of the Baptistery which is reflected in the wet churchyard of the Duomo anticipating, in a sense, those effects of transparency and reflection that often he will seek for the representations of his architecture for future publications.

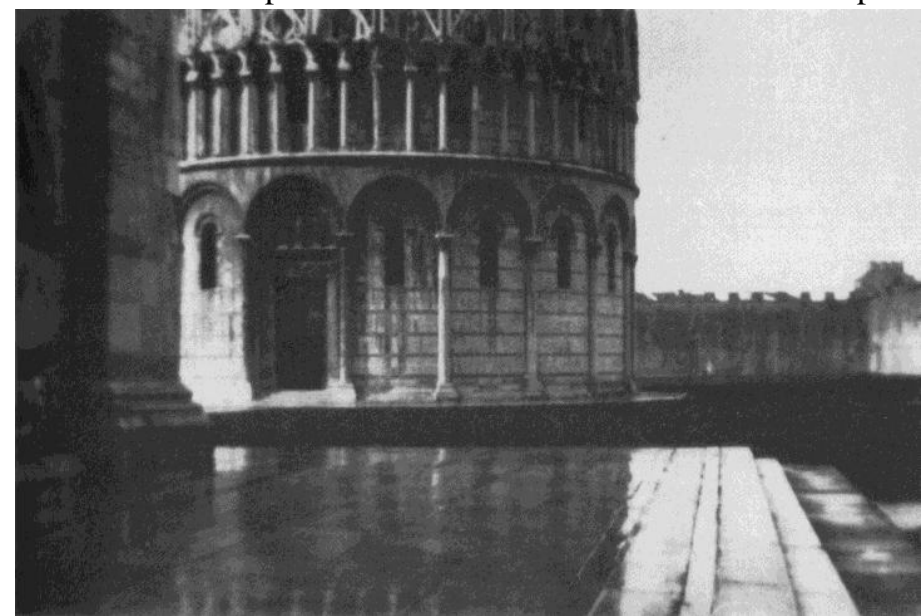

6. Le Corbusier, Pisa (October, 1911). Baptistery seen from the parvis of the cathedral (from Gresleri G., Op. Cit., p. 385). 


\section{2 ...to the nature}

In 1936 Le Corbusier shall provide itself with a cutting edge camera, the Siemens B16mm, and within two years produces about 120 shots and 6000 snaps that, as states Tim Benton, show a hidden aspect of the architect ${ }^{12}$. From this moment on, the photograph becomes an expression of personal emotions and a plastic and artistic search tool. Its use is increasingly connected to cinematographic experiments and, in this period, the architect also begins to check the possibilities of exchange and interaction between drawing, photography and cinema. Experiences that will converge, many years later, into the realization of the Philips Pavilion in Brussels (1958) in which photos, movies and music give rise to a Poéme élecronique ${ }^{13}$. A sort of concretization of what MoholyNagy had already guessed in 1922 when in his article "Produktion-Reproduktion", published in De Stijl, talks about new forms of production and representation, consistent with the technological age, based on the interaction of cinema, music and photography, can reveal previously unknown realities ${ }^{14}$.

In the '30s the subjects of the photographs by Le Corbusier change profoundly. The urban areas, buildings and architectural details of his early works characterized by the search for references to the practical work, leave room to snaps more intimate and personal. Pictures of loved ones (mother, girlfriend, friends and even his dog), resorts (as Piquey in the Bassin d'Arcachon, where he spends the holidays) seafaring themes, boats, fishermen, common items and building materials, natural elements become protagonists of his representations.

The so-called "objet trouvé" of the artists of the early Twentieth century, "objects à réaction poétique" for Le Corbusier, - found objects, waste and scrap loads of history, biological forms, signs and footprints in the sand arouse emotions and anxieties and they are the source of inspiration for many of his paintings and even for his architectures.

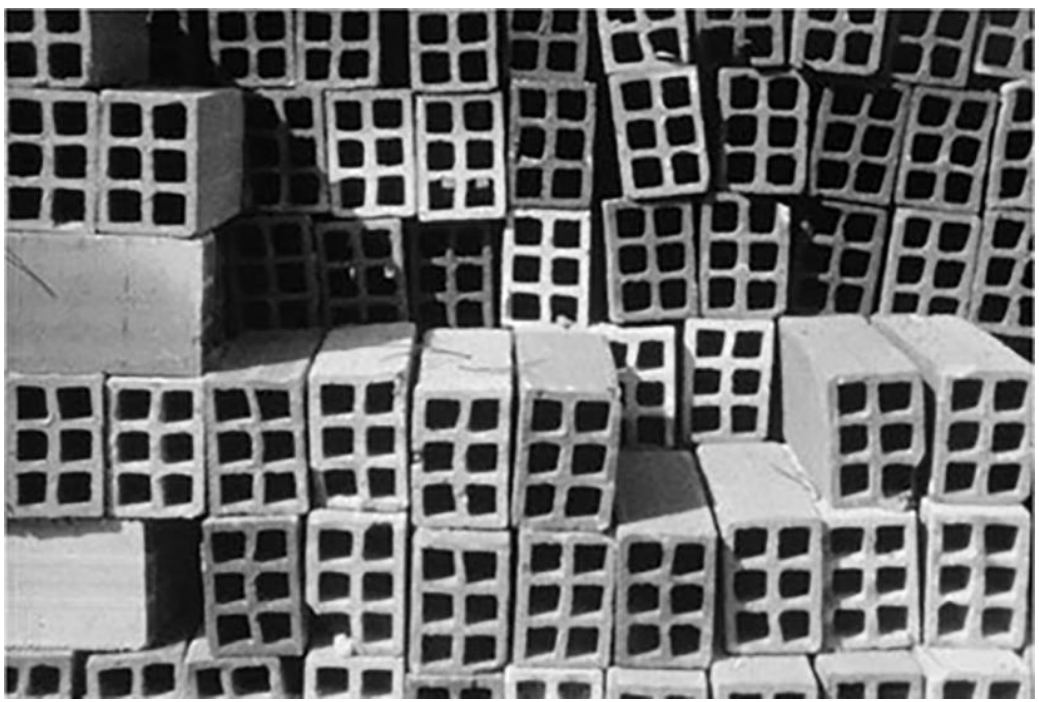

7. Le Corbusier, Piquey (1936-37). Industrial building materials (from AAVV, Construir...p.51).

\footnotetext{
${ }^{12}$ Benton is the author of several studies on Le Corbusier photographer. Here: Benton Tim, "Le Corbusier. Photographe secret", in AA. VV. Construire l'image. Le Corbusier et la photografie, Paris: Éditiòn Textuel, 2012, p.32.

${ }^{13}$ Fanelli Giovanni, Storia della fotografia di architettura, Roma-Bari: Laterza, 2009, p.430-32.

${ }^{14}$ Moholy-Nagy Lásló, Produktion-Reproduktion, in “De Stijl”, V, 1922, n.7, pp. 98-100, opera citata in Mazza B. (2002), Op. cit., p.70.
} 


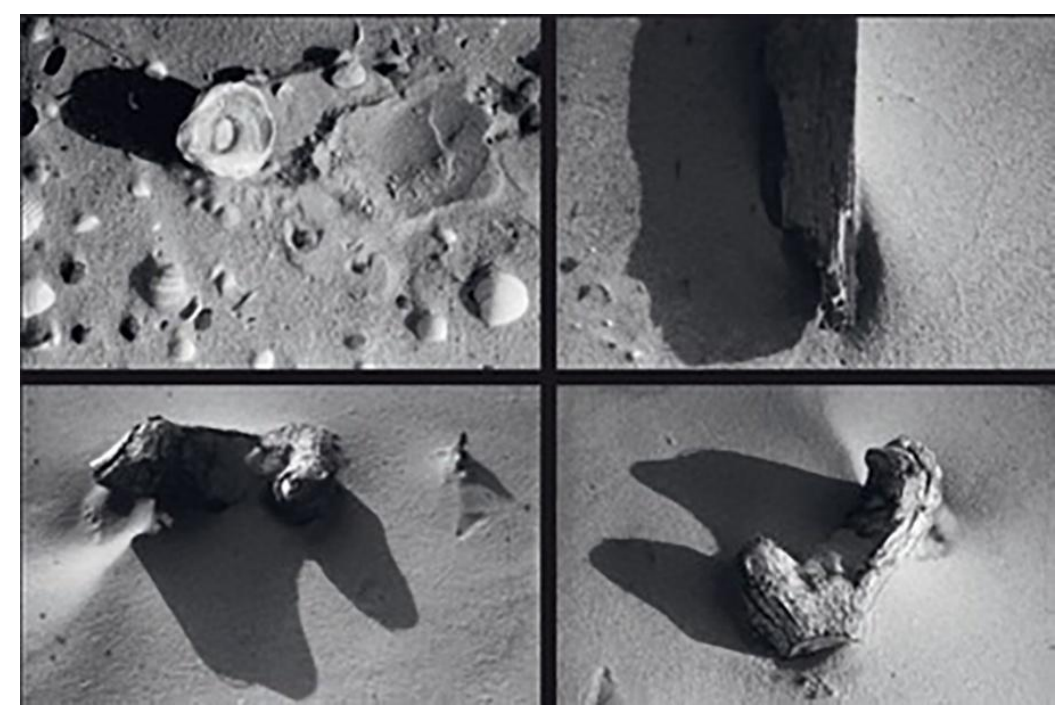

8. Le Corbusier, Piquey (September 1936). "Objects à réaction poétique” on the beach (from AAVV, Le Corbusier. Aventures...p.61).

Bones, shells, stones, pieces of bark, roots and mechanical parts, are collected, photographed and drawn repeatedly to reveal the beauty of form, the precision of the work of nature and their structure.

The eye of the painter seems more present than ever and the compositions become more and more abstract and symbolic also through the use of image sequences separated by white or black banding or in continuous succession. Horizontal or vertical bands that demonstrate a clear link with the cinema and tell the architecture but also what draws the attention of Le Corbusier photographer and artist. Exemplifying is the sequence of about 500 shots made on board the ocean liner Conte Biancamano during the traveling in Brazil (1936), images that explore the details and mechanics of the ship.

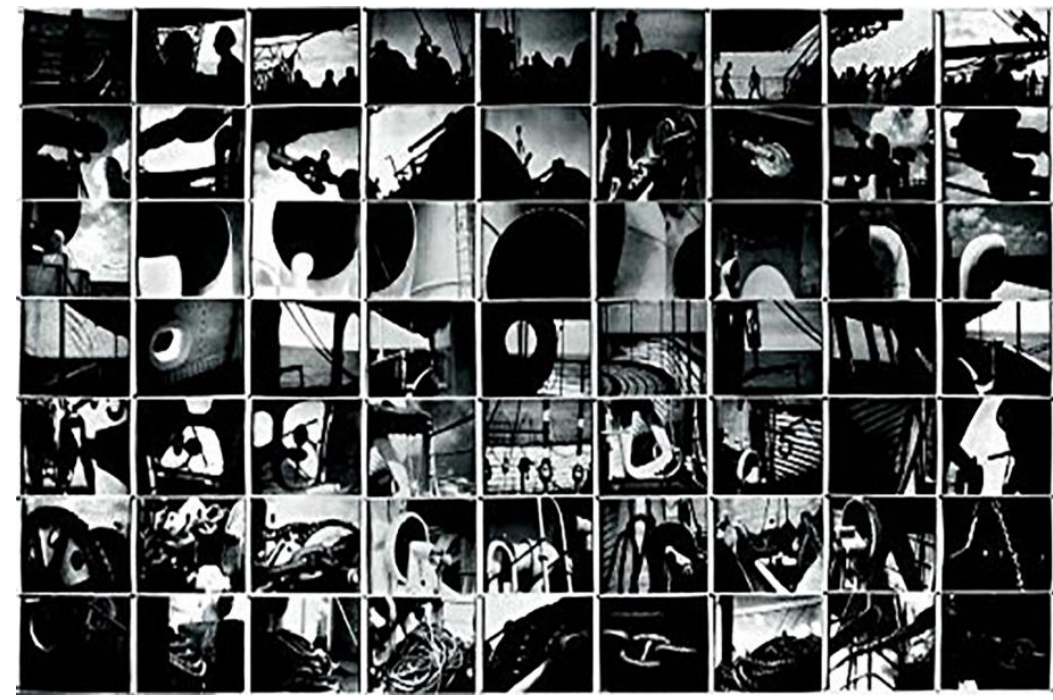

9. Le Corbusier, (August 1936). Collage of 63 photographs taken aboard the ocean liner Conte Biancamano, (from AAVV, Le Corbusier. Aventures...p.66).

The detachment from any reference dimensional, chased so many years before during the Journey to the East, when the architect, reflecting on St. Sophia and on the Galata Tower in Istanbul, asserts that to achieve a monumental and grandiose appearance it should avoid any reference to human scale and elements that can bring 
to $i^{15}$, now is functional to the dematerialization of shooted objects. The photographed objects, losing every real connotation, become generator centers of the surrounding space and have a strong emotional charge, a rich and imaginative aesthetic potential that becomes a source of inspiration for a new architecture.

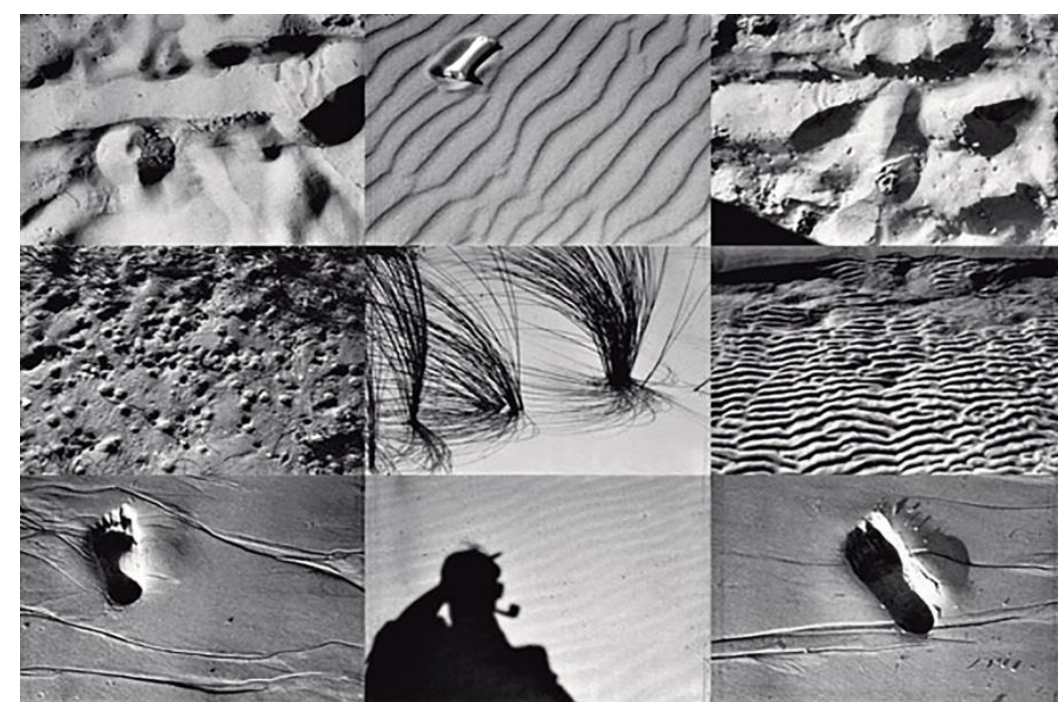

10. Le Corbusier, Piquey (1936-37). Photographs of the sand on the beach (from AAVV, Construir...p.47)

The growing interest in natural elements, in fact, corresponds to a progressive evolution of the architectural language: from the purism of the first period Le Corbusier switches to the style more "organic" that characterizes some emblematic works of the '50s. The turning point in the poetics of the architect seems to have already introduced by the proposals for the expansion plans of Rio and Algiers, with their flexuous configuration, the progressive abandonment of the abstract and austere style of the purist aesthetics, the loss of confidence in the progress made by the industrial technology.

From the rediscovery of the natural order of things spring the works called "brutalist" for the use of materials such as the coarse gravel, the unfinished wood, the brick facades and the béton brut. These are architectures with a free form, in which coexist elements inspired by the spontaneous construction techniques and advanced technology solutions. Among the most prominent examples: the Maison Errazuriz (1930) in Chile, with a sloping roof and built of wood and stone; the Petit Maison de Weekend (1935) built in Paris, with roofing in rough concrete vaults. Among the most mature and complex outcomes of the new brutalist aesthetic we find the Unité d'Habitation (1947-1952) of Marseilles and his buen retiro Le Cabanon (1952), a "castle" of $3.66 \mathrm{~m}$ to $3.66 \mathrm{~m}$ in French Riviera made exclusively of wood and natural materials.

${ }^{15}$ Mazza B. (2002), Op. cit., p. 42. 


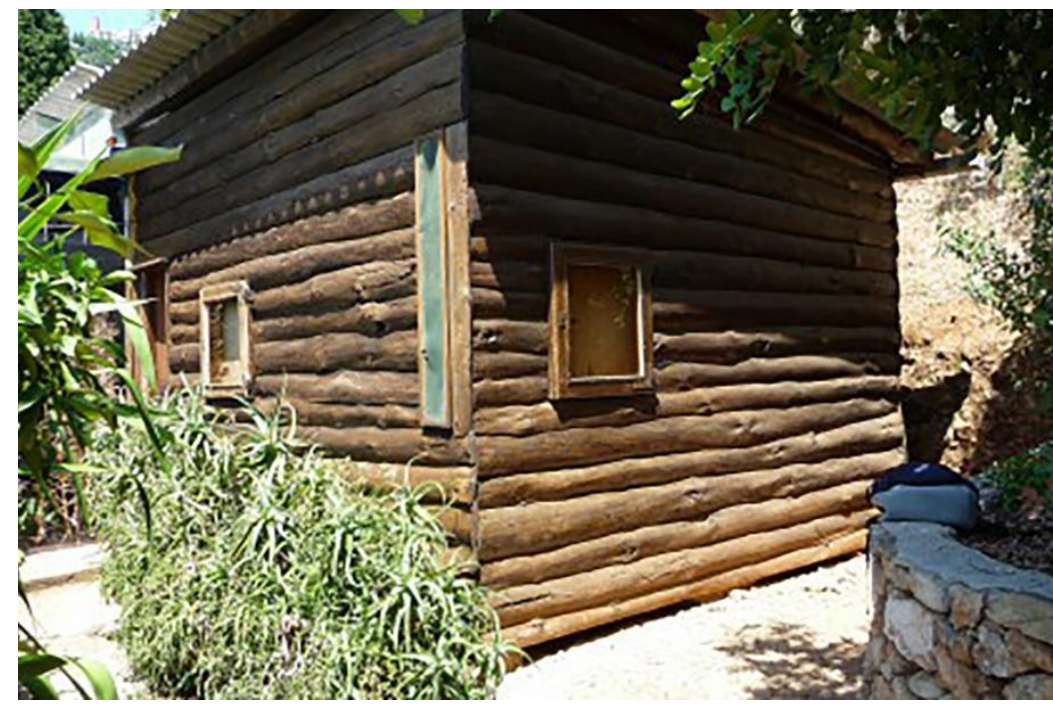

11. Le Corbusier, Roquebrune-Cap-Martin (1952). Vacation home Le Cabanon, (https://en.wikipedia.org/wiki/Cabanon_de_vacances\#/media/File:Cabanon_Le_Corbusier.jpg)

But the work that more than any other symbolizes the achievement of the "ineffable space" is certainly the Chapel of Ronchamp (Notre-Dame-du-Haut, 1950-1955), an architecture with sculptural forms, whose curves, turning to the four cardinal points, generate the space by wrapping the churchgoers inside and by embracing the natural universe on the outside. A work that many critics have metaphorically just assimilated to a shell, the shape so dear to Le Corbusier since his childhood.

\section{Conclusions}

Despite his initial preclusions, it is evident that also Le Corbusier is fascinated by photography and he immediately comprises its importance and validity as an analytical, communicative and informative tool.

Already from his youth "the eye of Jeanneret seems able to grasp from all that is built and from all fact of custom the particularity that constitutes the uniqueness of the work, its essence, its all"16. And perhaps the search for this essence is the thread that connects all the conspicuous photographic production of the Swiss master: from the youth shots that intend to retain the exact memory of locations and fragments of reality, to those of maturity that aim to the abstraction and to the complete dematerialisation of the shooted object

Beyond the different objectives of his shots, Le Corbusier never uses passively the camera but try to master the instrument and enslave it to his practical needs or to his artistic poetry ${ }^{17}$. His shots, regardless of poor technical quality, show immediately a very personal character for the chosen subjects and for their compositional structure. Photography for him is a kind of private note and rarely he publishes his shots. And is in this fact that finds confirmation and explanation the term coined by Benton's of "secret photographer"18.

\footnotetext{
${ }^{16}$ Gresleri G. (1995), Op. Cit., p.12.

17 The subjects and the unusual shots of his photos of travel and the many manipulations of images for studies and publications of his own or others' architectures respond to this logic: photomontage, collage, retouching, printing on the reverse or rotated to show the value of an architectural composition balanced and well calculated, regardless of the direction of observation, games of optical and spatial illusionism.

${ }^{18}$ Benton Tim, Le Corbusier Secret Photographer, Zurich: Lars Müller Publishers, 2013.
} 
The relationship between Le Corbusier and photography, therefore, is very long and controversial, passes through all his long personal and professional life and undergoes significant transformations that, such as in a hall of mirrors, reflect the evolution of his thought and of his artistic and architectural poetics.

\section{Images sources}

1. Gresleri G., Le Corbusier, Viaggio in Oriente. Charles, Edouard Jeanneret fotografo e scrittore, VeneziaParigi: Marsilio-Fondation Le Corbusier, 3rd ed. 1995, pp. 156 e 157.

2. Gresleri, Le Corbusier, Op.cit., p. 175.

3. Gresleri, Le Corbusier, Op.cit.,p. 193.

4. Gresleri, Le Corbusier, Op.cit., p. 206.

5. Gresleri, Le Corbusier, Op.cit, p. 272.

6. Gresleri, Le Corbusier, Op.cit, p. 385.

7. AAVV, Construire l'image: Le Corbusier et la photographie, Paris: Thames \& Hudson/Textuel, 2012, p.51.

8. AAVV, Le Corbusier. Aventures photographiques, Paris: Fondation Le Corbusier, 2014, p.61.

9. AA VV., Le Corbusier. Aventures...p.66.

10. AAVV, Construir...p.47.

11. https://en.wikipedia.org/wiki/Cabanon_de_vacances\#/media/File:Cabanon_Le_Corbusier.jpg

\section{Bibliography}

AAVV, Construire l'image : Le Corbusier et la photographie, Paris : Thames \& Hudson/Textuel, 2012.

AAVV, Le Corbusier. Aventures photographiques, Paris: Fondation Le Corbusier, 2014.

Banham Reyner, A Concrete Atalantis. U.S. Industrial Building and European Modern Architecture, CambridgeLondon: Mit-Pr 1986.

Benton Tim, Le Corbusier Secret Photographer, Zurich: Lars Müller Publishers, 2013Fanelli Giovanni, Storia della fotografia di architettura, Roma-Bari: Laterza, 2009.

Gresleri Giuliano, Le Corbusier, Viaggio in Oriente. Charles, Edouard Jeanneret fotografo e scrittore, VeneziaParigi: Marsilio-Fondation Le Corbusier, 3rd ed. 1995.

Mazza Barbara, Le Corbusier e la fotografia. La vérité blanche, Firenze: University Press, 2002.

Zannier Italo, "Nota a margine su Le Corbusier fotografo", in Le Corbusier, Viaggio in Oriente. Charles, Edouard Jeanneret fotografo e scrittore, edizione di Giuliano Gresleri, Venezia-Parigi: Marsilio-Fondation Le Corbusier, 3ed 1995, p. 479-482. 